\title{
BABY STEPS AWAY FROM THE STATE: REGIONAL JUDICIAL INTERACTION AS A GAUGE OF POSTNATIONAL ORDER IN SOUTH AMERICA AND EUROPE
}

\author{
Tom Gerald Daly*
}

\begin{abstract}
This paper explores the difference between 'universality', 'cosmopolitanism' and 'internationalisation' by contrasting judicial dialogue and community in Europe and South America; two regional constellations which include national orders, regional human rights systems and the legal orders of regional integration projects. By focusing on the relatively underdeveloped and fragmented nature of regional integration, judicial dialogue and community in South America, the paper emphasises that the region does not simply replicate the European experience. Law and the courts in South America have not 'stepped away' from the state to the same extent, with the result that the region cannot be characterised as a postnational order in the European mould.
\end{abstract}

\section{Keywords}

Postnational order, judicial dialogue, judicial community, Europe, South America

\section{Introduction}

In Europe's 'postnational constellation'1 of interlinked national, supranational and international human rights legal orders a true regional community of courts exists. Apex national courts are not only required to regularly apply exogenous norms and to engage in mutual cooperation, but are also increasingly wont to voluntarily refer to foreign and European jurisprudence and to engage in transnational networks for exchanging case-law and discussing common issues.

From a distance South America appears similar, with a regional constellation including domestic orders, the Inter-American human rights system and the legal

\footnotetext{
Ph.D Candidate, University of Edinburgh Law School, B.L. (King's Inns), LL.M (Florence), BCL Law and French (NUI). The author's doctoral research is generously supported by a Travelling Studentship in International Law from the National University of Ireland (NUI).

${ }^{1}$ Kuhm uses the term to describe the global order, but it is an equally apt description of the European regional order. See: M Kuhm, "The Best of Times and the Worst of Times: Between Constitutional Triumphalism and Nostalgia' in P Dobner and M Loughlin (eds), The Twilight of Constitutionalism? (2010) 201.
}

Copyright $\odot$ the Author(s).

This work is licensed under a Creative Commons Attribution-NonCommercial-NoDerivs 3.0 License. 
orders of regional integration projects. In the wave of democratisation since the late 1970s, many states have also experienced an 'internationalisation' of constitutional law and 'judicialisation' of politics; with a tendency to accord constitutional status to international human rights law, and with the Inter-American Court of Human Rights in particular providing a lodestar to national courts carving out a new role for themselves at the centre of the constitutional system. Like Europe, there is a familiar sense of law, and courts, stepping away from the State.

However, there are vital differences between South America and Europe which merit analysis; not only to avoid mischaracterising the South American context as merely replicating the European experience, but also to add to our overall understanding of the relationship between 'universality', 'cosmopolitanism' and 'internationalisation'. By exploring the relatively underdeveloped and fragmented nature of regional integration, judicial dialogue and community in South America this paper emphasises that law and courts in the region have not 'stepped away' from the state to the same extent as observed in Europe, with the result that the region cannot be characterised as a postnational order in the European mould.

Finer-grained analysis of the South American context is pursued by briefly contrasting the 'universalist' Argentine Supreme Court with its 'sovereigntist' Brazilian counterpart; the former appearing more open to internationalisation than the latter, which combines a strong tradition of cosmopolitanism with a marked resistance to sharing normative supremacy with any international court-a stance now alien to Europe, but also different to that found in the United States.

\section{Setting the Scene}

Recent decades have witnessed an ever expanding literature on the shift of law from the nation state, both in the global arena and the regional sphere. At the global level, the tectonic forces of globalisation in the legal, regulatory and economic spheres have led scholars to question whether sovereignty as a principle is dead in international politics, ${ }^{2}$ or needs to be re-worked to have any enduring purchase as an organising principle in the pursuit of world order. ${ }^{3}$ Law, long

\footnotetext{
${ }^{2}$ See: K Sietzy, 'Is Sovereignty Dead as a Principle in International Politics?' <http://www. academia.edu/ 3584274/Is_Sovereignty_Dead_as_a_Principle_in_International_Politics> [accessed 20 December 2014].

${ }^{3}$ See: T Jacobsen, CJG Sampford \& R Chandra Thakur (eds), Re-envisioning Sovereignty: The End of Westphalia? (2008).
} 
bound to the notion of the state, has been loosed from its conceptual moorings, with the language of international law-the 'law of nations'-expanding to accommodate new terminology: a ius gentium', 'humanity's law', 'lex pacificatoria' ${ }^{6}$ and even 'global law'; 7 all identifying jurisgenerative processes that transcend the state, or non-state centres of gravity for the elaboration of legal frameworks. In the European context the trend is even more striking: we have become inured to the notion of legal pluralism, with a diminution of the state's status as privileged producer of law.

Courts have played a central part in this phenomenon (or, related phenomena). There now exists a significant body of scholarship on the role of courts in the unfolding reality of regional integration, international regime construction, and the development of international law in the broadest sense, as well as the challenges for courts in addressing horizontal and vertical tensions and threats of international law fragmentation generated by these processes. ${ }^{8}$ The proliferation of international courts, judicial machinery of regional integration projects and other adjudicative bodies has required a reconceptualisation of what a court is, and what is expected of judges. ${ }^{9}$ Domestic courts, for their part, have become expected to act as partners in a shared endeavour to apply international law and supranational law, whether by voluntarily receiving international human rights norms, directly applying supranational law, or acting as 'international courts' in discrete domains (e.g. universal criminal jurisdiction).

Against the operatic setting of the existing literature this paper has a rather modest objective: to compare the nature of judicial dialogue and community in

${ }^{4}$ J Waldron, 'Foreign Law and the Modern Ius Gentium' (2005) 119 Harvard LR 129.

5 R Teitel, Humanity's Law (2011).

${ }^{6}$ C Bell, On the Law of Peace: Peace Agreements and the Lex Pacificatoria (2008).

7 N Walker, Intimations of Global Law (2014).

8 A-M Slaughter, AS Sweet \& JHH Weiler (eds), The European Court and National Courts: Doctrine and Jurisprudence (1998); K Nyman-Metcalf and I Papageorgiou, Regional Integration and Courts of Justice (2005); M Forowicz, The Reception of International Law in the European Court of Human Rights (2010); N Nabil Jurdi, The International Criminal Court and National Courts: A Contentious Relationship (2011); A Rosas, E Levits \& Y Bot (eds) The Court of Justice and the Construction of Europe: Analyses and Perspectives on Sixty Years of Case-law (2012); N Boschiero, T Scovazzi, C Pitea \& C Ragni (eds), International Courts and the Development of International Law: Essays in Honour of Tullio Treves (2013); A Føllesdal, B Peters \& G Ulfstein, Constituting Europe: The European Court of Human Rights in a National, European and Global Context (2013); K Dzehtsiarou, T Konstadinides, T Lock \& N O'Meara (eds), Human Rights Law in Europe: The Influence, Overlaps and Contradictions of the EU and the ECHR (2014).

9 See: D Terris, C Romano \& L Swigart, The International Judge: An Introduction to the Men and Women who Decide the World's Cases (2007). 
the regional contexts of South America and Europe in order to draw out the stark differences between the two, and the differing diminution of the state, in each context.

\subsection{Universality, Cosmopolitanism and Internationalisation}

The concepts of universality, cosmopolitanism and internationalisation interact in the regional context in a different manner than the global context, especially when viewed from the perspective of national courts.

Universality, denoting the equal and indiscriminate application of international law across national legal systems and across discrete international regimes, is both strengthened and challenged in regional contexts containing integration projects and regional human rights regimes. Such regional regimes tend to prise open the 'black box' of the domestic legal order to a much greater extent than traditional international law, with its limited tools of ius cogens, treaties and conventions: national courts face not only the binding norms of international law-the impact of which depends both on the status accorded to international law in the domestic order, and the stance of national courts themselves-but also binding norms and judgments of regional courts, which further narrow the parameters of domestic courts in interpretation of the law. Although these regional orders on rare occasions clash with overarching international law norms, ${ }^{10}$ the predominant effect is to enhance the penetration of international law in the domestic context by building on existing international agreements, amplifying the binding effect of international norms, and requiring greater interaction with international courts.

Cosmopolitanism, on the other hand, denotes a sense of identification and connection across geographical space through shared norms or aspirations, proceeding from a position of voluntariness. Analysis of cosmopolitanism in the courts tends to focus largely on the increasing propensity of domestic courts

\footnotetext{
${ }^{10}$ Epitomised by the Kadi saga that pitted EU law against binding UN Security Council resolutions: Case C-402/05 P and C-415/05 P, Kadi and Al Barakaat International Foundation v Council and Commission, Judgment of the Court (Grand Chamber) [2008] ECR I-6351 (Kadi I); and Case C-584/10 P, C-593/10 P and C-595/10 P, European Commission and Others $v$ Yassin Abdullah Kadi, Judgment of the Court (2013) (Kadi II). In the area of regional human rights the circumscribed right to consent for indigenous communities concerning the exploitation of indigenous lands recognised by the Inter-American Court of Human Rights diverges from the more expansive right enshrined in the 2007 UN Declaration on the Rights of Indigenous Peoples, which has no adjudicative machinery of its own. See: Saramaka People v Suriname (2008) IACtHR Ser C No 172.
} 
to voluntarily cite foreign jurisprudence in seeking solutions to domestic legal problems, but also analyses the capacity for voluntary transnational judicial interaction to create and uphold international law. ${ }^{11}$

If universality can be characterised as a principle and cosmopolitanism as primarily a worldview or methodology, internationalisation is best viewed as a process, underpinned and sustained by the interactive relationship of both. It is evidently often spurred outwith the courts; clear examples being the strong influence of international law on constitution-making in states of the third wave' of democratisation since the 1970s and the longstanding and increasing transplantation of law and legal institutions (e.g. civil codes, juries). However, courts are central actors: although political actors play a core role, the trajectory and success of regional integration projects, the status of international law in the domestic order, states' capacity to engage in transnational and pan-regional cooperation and the friction generated between orders hinges, in large part, on judges, with the lines between universality and cosmopolitanism-what is required versus what is desired - tending to become blurred at times.

\subsection{Judicial Dialogue and Community}

With the above as the overall backdrop, the meaning of judicial dialogue and community can be analysed in greater detail. In her seminal 2003 article, AnneMarie Slaughter described the growing interaction between courts worldwide as a 'global community of courts', with two dominant strands: constitutional crossfertilisation through increasing citation by constitutional courts of the jurisprudence of courts in other countries, amounting to a form of transnational judicial dialogue; and active cooperation and occasional conflict between national courts addressing transnational litigation in cross border disputes. ${ }^{12}$

Slaughter painted a picture of the 'self-aware' construction of a community based on participation in a 'common judicial enterprise', which tends to cut across state boundaries: international courts becoming less deferential to traditional conceptions of state sovereignty; the notion of 'judicial comity' usurping the 'comity of nations' as the guiding principle of transnational judicial cooperation;

11 See generally: A-M Slaughter, 'A Global Community of Courts' (2003) 44 Harvard ILJ 191; M Kirby, 'Transnational Judicial Dialogue: Internationalisation of Law, and Australian Judges' (2008) 9 MJIL 171; M Schor, 'Mapping Comparative Judicial Review' (2008) 7 Wash U Glob Stud LR 257; M Waters, 'Mediating Norms and Identity: The Role of Transnational Judicial Dialogue in Creating and Enforcing International Law' (2005) 93 Geo LJ 487.

12 Slaughter, above n 11. 
and courts given leeway by national governments to create their own regimes for cooperating in the resolution of transborder disputes. ${ }^{13}$

This view has been subjected to criticism, not least on the basis that 'dialogue' is an inapposite metaphor, both conceptually and empirically, for much of the interaction between judges worldwide; particularly the growing worldwide citation of the case-law of a small cohort of prestigious constitutional courts. Face-to-face meetings and international judicial conferences remain perhaps the only clear examples of true dialogue. ${ }^{14}$ The metaphor of 'global community', on the other hand, can also be a little vague; tending to hide the fact that transborder judicial interaction is much more intense in some regions, and between certain courts, than others. ${ }^{15}$

For the purposes of this paper, regional judicial interaction is viewed as a spectrum, from weak interaction ('community') to strong interaction ('dialogue'), incorporating case-law citation, voluntary cooperation in transnational litigation, mandatory cooperation under formal regimes (e.g. preliminary references by national courts to supranational courts and mutual cooperation between national courts), and finally, judicial networking, including face-to-face interaction.

\section{Regional Differences; or, Why South America is Not Europe}

This section explores the different nature of judicial dialogue and community in South America, compared to Europe, by reference to three central differences: the nature of regional integration projects; the nature of the regional human rights protection system; and the nature of regional judicial networks. It is worth emphasising that no normative argument is being advanced that one region is better than the other; and in particular, no argument that South America should emulate the European experience. First, a brief commentary on the European context.

\footnotetext{
${ }^{13}$ Ibid, 192-3, 213.

${ }^{14}$ See: DS Law \& WC Chang, 'The Limits of Global Judicial Dialogue' (2011) 86 Wash LR 523.

${ }^{15}$ This is also, to some extent, true of notions such as a 'global judicial network'. See: MA Jayatilake, 'The Global Judicial Network: Towards New Hope for Development, Democracy and Equality in the Global Era' (2009) 21 Sri Lanka JIL 137.
} 


\subsection{The European Experience in Brief}

The European experience of an evolving postnational order has been well rehearsed elsewhere and need not detain us for very long. At its core are two separate and parallel, but interlinked, projects-the European Convention on Human Rights system and the European Union $(E U)$-which have developed in tandem, whose interaction has become increasingly intense, and which have transformed the nature of judicial dialogue and community in Europe. ${ }^{16}$

The European Convention system began with establishment of the Council of Europe in 1950 by ten states and adoption of the European Convention on Human Rights, ratified in 1953. Established in 1959, the European Court of Human Rights, after a gradual march of progress in its early decades, truly hit its stride in the 1980s, and became the sole adjudicative organ of the Convention system in the reforms of 1998, with jurisdiction over a vastly expanded membership following the accession of post-Communist and post-Soviet states. Today, the Convention exerts a strong influence on national legal orders through the requisite domestic 'incorporation' of the Convention, and use of the European Court's case-law as a legal standard for State activity and judicial interpretation of domestic law.

The EU began with establishment of the European communities in 1958 by six member states, with a permanent Court of Justice from the outset, which has been a central actor in the construction of the bloc's legal order. In a succession of landmark decisions, the Court characterised the community as an autonomous legal order transcending public international law, asserted the doctrines of the primacy and direct application of community law, and pre-emption, and calibrated the balance of powers between community organs. ${ }^{17}$ The Court thereby 'constitutionalised' the community's founding treaties and transformed national courts, private sub-state actors and citizens into agents of integration in a constructive enterprise that was not within the full control of the member state governments. The Court's case-law has underpinned, and been formally approved by, a series of treaties; culminating in the present Union, which, under the Treaty of Lisbon ${ }^{18}$ lays claim to a vast range of competences.

With the rise of these regimes national courts have become 'European' courts, in the sense that they apply EU law and request definitive interpretations of

\footnotetext{
${ }^{16}$ This paper does not consider other post-war European organisations without judicial architecture such as the Organisation for Economic Co-operation and Development (OECD).

${ }^{17}$ See: D Tamm, 'The History of the Court of Justice of the European Union Since its Origin' in A Rosas, E Levits \& Y Bot (eds) The Court of Justice and the Construction of Europe: Analyses and Perspectives on Sixty Years of Case-law (2012) 9.

${ }^{18}$ Treaty on the Functioning of the European Union, 26 October 2012, OJ C 326 (TFEU).
} 
EU law from the Court of Justice under the preliminary reference procedure ${ }^{19}$; and when they apply norms of the European Convention on Human Rights. The Court of Justice and the European Court of Human Rights, in turn, are now often viewed as 'constitutional' courts, as the judicial arms of the 'constitutionalised' order of the EU and the European Convention system, which has been characterised as 'a constitutional instrument of European public order (ordre public). ${ }^{20}$ The two separate regional orders have engaged in extensive cooperation to minimise divergences in their separate bodies of law. The ultimate step-accession of the EU itself to the European Convention system-is currently being worked out, ${ }^{21}$ although the Court of Justice's judgment of 18 December 2014 has been described as a 'bombshell' rendering accession 'very difficult, if not impossible. $^{22}$

These developments in the post-war decades have gradually acclimatised domestic apex courts to the sharing of judicial supremacy. In the EU they are required to operate in a pluralist context where neither they nor the Court of Justice can control the overall legal space. ${ }^{23}$ Threats arising from profound normative conflict, epitomised in the German Federal Constitutional Court's line of Solange case-law ${ }^{24}$ which asserted the Court's role as ultimate guardian of fundamental rights as against the Court of Justice, have not derailed the supranational train and courts in newer member states, strongly influenced by German law, ${ }^{25}$ have adopted a 'relatively balanced attitude' toward European integration and the principle of supremacy of EU law. ${ }^{26}$ At the same time, a progressive expansion of EU competences, particularly the aim of creating an Area of freedom, security and justice, has required increasingly intense engagement between national courts across the bloc, through mutual cooperation

19 TFEU Art 267.

${ }^{20}$ Loizidou v Turkey [1995] ECtHR App No 15318/89 (GC), para 75.

${ }^{21}$ A helpful overview is offered in K Dzehtsiarou, T Konstadinides, T Lock \& N O’Meara (eds), Human Rights Law in Europe: The Influence, Overlaps and Contradictions of the EU and the ECHR (2014).

22 See: S Douglas-Scott, 'Opinion 2/13 on EU accession to the ECHR: a Christmas bombshell from the European Court of Justice' (UK Const L Blog, 24 December 2014) <http://ukconstitutionallaw.org > [accessed 24 December 2014].

${ }^{23}$ See: S Douglas-Scott, 'Justice and Pluralism in the EU' (2012) 65 CLP 83.

${ }^{24}$ Judgment of 29 May 1974, 37 BVerfGE 271, 14 CMLR 540 (Solange I); and Judgment of 22 October 1986, 73 BVerfGE 339 (Solange II).

${ }^{25}$ See: AF Tatham, Central European Constitutional Courts in the Face of EU Membership: The Influence of the German Model in Hungary and Poland (2013).

${ }^{26}$ D Piqani, 'Constitutional Courts in Central and Eastern Europe and their Attitude towards European Integration' (2007) 1 EJLS 1, 20. 
and mutual assistance in transnational cases, concerning criminal matters (e.g. extradition) and civil matters (e.g. child protection). In the European Convention context it has been suggested that a 'fruitful dialogue has developed between the Strasbourg institutions and domestic courts whose respective case law mutually support and enrich each other ${ }^{27}$ and the Strasbourg Court has shown itself willing to accommodate and respond to occasional challenges to its jurisprudence by domestic courts. ${ }^{28}$

These regional developments have been accompanied by a dramatic proliferation of judicial networks, particularly since 2000. In the EU a number of formal networks have been established to pursue EU justice goals, such as the European Judicial Network $(E J N),{ }^{29}$ as well as other organisations aimed at fostering a greater sense of judicial community, such as the Network of Presidents of Supreme Judicial Courts of the EU and the Association of the Councils of State and Supreme Administrative Jurisdictions of the EU (ACA-Europe). ${ }^{30}$ A host of other organisations aiming to connect judges across the EU and the European Economic Area (EEA) operate outside the formal aegis of the EU. ${ }^{31}$

Within the Council of Europe there are three key networks, with a strong focus on constitutional courts: the Conference of European Constitutional Courts (CECC); the Consultative Council of European Judges (CCJE); and the Venice Commission's Joint Council on Constitutional Justice, which gathers together representatives of each constitutional court across the 47 member states. Beyond this, European courts participate in global networks based on a shared language, ${ }^{32}$ networks that are looser in nature ${ }^{33}$ and ad hoc groupings that link

${ }^{27}$ D Shelton, The Regional Protection of Human Rights (2010) 20.

${ }^{28}$ See: W Thomassen, 'The vital relationship between the European Court of Human Rights and national courts' in SI Phlogaitēs, T Zwart \& J Fraser (eds), The European Court of Human Rights and its Discontents: Turning Criticism Into Strength (2013) 96.

${ }^{29}$ The EJN was created by the Joint Action 98/428 JHA of 29 June 1998 to fulfill recommendation 21 of the Action Plan to Combat Organised Crime.

${ }^{30}$ See: <http://www.network-presidents.eu> [accessed 1 January 2015] <http://www.acaeurope.eu/index.php/en> [accessed 1 January 2015].

31 These include the Association of European Competition Law Judges (AECLJ), the Association of European Administrative Judges $(A E A J)$, the European Association of Labour Court Judges, the EU Forum of Judges for the Environment, and the European Judges and Prosecutors Association.

32 The principal organisations are the hispanophone Ibero-American Conference of Constitutional Justice, the lusophone Conference of Constitutional Jurisdictions of the Portuguese-Speaking Countries (CJCPLP) and the francophone Association des Cours Constitutionnelles ayant en Partage l'Usage du Français (ACCPUF).

${ }^{33}$ These would include the European Association of Judges $(E A J)$ and its parent organisation, the International Association of Judges $(I A J)$, and other bodies such as the International Association 
smaller groups of states. ${ }^{34}$

Contrary to the suspicions of some scholars ${ }^{35}$ the present author, from personal experience working at the Supreme Court of Ireland, ${ }^{36}$ can attest that these are neither collusive networks, like some sort of judicial illuminati, nor confined to mere small talk. Rather, they are open about their integrative agendas and do foster dialogue on substantive issues, and a pan-regional sense of community, by facilitating regular meetings of judges; conferences on selected themes; databases which collect national case-law under one roof and make foreign case-law more accessible; ongoing information exchange; thematic questionnaires; and even an EU-wide judicial exchange programme. The formal EU bodies and the Venice Commission lead the pack, being the best-resourced and with the most extensive networks and activities. Indeed, in the EU context, 'judicial integration' can run ahead of state-driven integration: it has been observed, for instance, that member state disagreement on the harmonisation of national law in order to create a regional area of security, freedom and justice has been partly 'balanced' by the activity of judicial networks. ${ }^{37}$

What exists, then, is a prismatic epistemic community of national and regional courts, involved in overlapping enterprises which, despite occasional friction, can be said to constitute a common endeavour. This is true, at least, of EU member states-Council of Europe member states outside the EU occupy a different position. The next three sections explore the South American context, which differs in many respects.

\subsection{Regional integration in South America}

A core difference between Europe and South America is the lack of any true equivalent of the European Union in the latter region. Although regional political integration projects date to the post-independence climate of the

of Supreme Administrative Jurisdictions (IASAJ).

${ }^{34}$ For example, the Franco-British-Irish Judicial Committee, which links judges from the three states.

${ }^{35}$ Law \& Chang, above n 14, 535-6.

${ }^{36}$ The author was Executive Legal Officer to the Chief Justice from 2006 to 2011, a role with a significant international relations focus, including attending international judicial conferences, acting as liaison officer to various bodies, such as the Venice Commission's Joint Council on Constitutional Justice, and designing study programmes for visiting judges.

${ }^{37}$ M Magrassi, 'Reconsidering the Principle of Separation of Powers: Judicial Networking and Institutional Balance in the Process of European Integration' (2011) 3 Contemp Read L \& Soc Just 159. 
nineteenth century, ${ }^{38}$ economic integration bodies only appeared in the 1960s. The first project, the pan-regional Latin American Free Trade Association (LAFTA39) established in 1960, was a failure, dominated by the larger economies and producing few benefits for smaller economies. ${ }^{39}$ Abandoned by four northwestern states in 1966 (Bolivia, Colombia, Ecuador and Peru) to form the Andean Pact in 1969 (becoming the Andean Community (CAN) in 1996 ${ }^{40}$ ), it was finally replaced by the Latin American Integration Association $(A L A D I)^{41}$ in 1980, a more enduring organisation which focuses on assistance for less developed economies as well as free trade. ${ }^{42}$ In the Southern Cone MERCOSUR (the Common Market of the South ${ }^{43}$ ) was established in 1991 to foster a free trade area between Brazil, Argentina, Paraguay and Uruguay, with Venezuela joining in 2012 and Bolivia currently in the accession process.

Although a number of other integration projects have emerged with differing memberships, purposes, and political leanings (e.g. the Pacific Alliance ${ }^{44}$ ), the Andean Community and MERCOSUR remain the key bodies given that they are the longer-established organisations and are the key components of the new region-wide integration project, the Union of South American States (UNASUR). Effectively an integration agreement between the two blocs enshrined in a Constitutive Treaty of $2008,{ }^{45}$ if successful UNASUR would integrate all hispanophone states and Brazil in South America. As such, it marks the first fully-fledged attempt at pan-regional integration, though still operating within the looser, overarching framework of ALADI. ${ }^{46}$ At present, UNASUR's

\footnotetext{
${ }^{38}$ See: J Bennett, 'The Union of South American Nations: The New(est) Regionalism in Latin America' (2008-2009) 32 Suff Transn'l LR 103, 104.

${ }^{39}$ Ibid, 108-9.

${ }^{40}$ See: <http://www.comunidadandina.org > [accessed 1 January 2015].

${ }^{41}$ See: <http://www.aladi.org/> [accessed 1 January 2015] The current members are Argentina, Bolivia, Brazil, Chile, Colombia, Cuba, Ecuador, Mexico, Panama, Paraguay, Peru, Uruguay and Venezuela.

${ }^{42}$ Bennett, above n 38, 110-1.

${ }^{43}$ Mercado Común del Sur, or in Portuguse, Mercado Comum do Sul. See: <http://www.mercosur.int/msweb/portal\%20intermediario> [accessed 1 January 2015].

${ }^{44}$ Alianza del Pacífico, <http://alianzapacifico.net/en> [accessed 1 January 2015]. Members: Chile, Colombia, Mexico and Peru. The Bolivarian Alliance for the Peoples of Our Americas (Alianza Bolivariana para los Pueblos de Nuestra América, ALBA) only includes two South American states: Bolivia and Venezuela. All other member states are Central American and Caribbean states.

${ }^{45}$ Adoption of the Constitutive Treaty was preceded by two key measures: reciprocal acceptance by each bloc of the other's members as associate members in the early to mid 2000s, and establishment of the South American Community of Nations $(S A C N)$ by the Cusco Declaration in 2004, which was superseded by UNASUR.

${ }^{46}$ Bennett, above $\mathrm{n} 38,123 \mathrm{ff}$. The text of the Constitutive Treaty is accessible at: <http://www.una-
} 
institutional development is in its infancy, and its aims are pursued largely through the two constituent blocs which remain the only regional projects with judicial architecture in place. ${ }^{47}$

MERCOSUR's judicial machinery languishes at a low level of institutional development, reflecting the development of MERCOSUR as a whole, which remains wedded to intergovernmentalism-or even more narrowly, interpresidentialism. ${ }^{48}$ The Argentine and Brazilian presidents act as the 'natural hegemons', with Uruguay and Paraguay overshadowed and Venezuela a wild card thrown into the mix; all harbouring different visions for the integration project. ${ }^{49}$ This has stifled the development of MERCOSUR institutions. A quasi-executive body ${ }^{50}$ established in 2003 and a parliament with 'quasi-legislative powers' established in $2005^{51}$ have been largely inactive. Adjudicative organs established in 2002 consist of ad hoc arbitration tribunals and an appellate arbitral body, the Permanent Review Court (Tribunal Permanente de Revision), with the power to issue decisions in disputes as well as advisory opinions on MERCOSUR norms when requested by member states, MERCOSUR organs or member state supreme courts. However, these have been similarly inert.

MERCOSUR member states have been slow to accept the Permanent Review Court's jurisdiction $^{52}$ and, to date, recourse to these bodies has been rare. The Court has been reluctant to impose sanctions where violations of community law are found, and even where sanctions are imposed, they are ignored due to the absence of any meaningful enforcement mechanisms. ${ }^{53}$ Even if the situation

sursg.org/uploads/0c/c7/0cc721468628d65c3c510a577e54519d/Tratado-constitutivo-englishversion.pdf> [accessed 1 January 2015].

47 That said, the possibility of a pan-regional UNASUR court has been debated since 2008 and the new Secretary-General of UNASUR, Ernesto Samper, has indicated a desire to create a Regional Criminal Court to try transnational crimes, which may prove to be the first step in a UNASUR court system. See 'New Unasur Secretary-General Ernesto Samper to Fight Inequality and Insecurity', Telesur, available at: <http://www.telesurtv.net/english/news/Unasur-Head-ErnestoSamper-Pledges-to-Empower-the-Region-20140904-0078.html> [accessed 1 January 2015].

${ }^{48}$ RA Porrata-Doria Jr, 'MERCOSUR at Twenty: From Adolescence to Adulthood' (2013) 27 Temple ICLJ $1,16$.

${ }^{49}$ Ibid, $16 \mathrm{ff}$.

50 The Committee of Permanent Representatives (COREPER) is composed of the president and one additional representative from each member state.

${ }^{51}$ The MERCOSUR parliament (PARLASUR) replaced the Joint Parliamentary Commission; Porrata-Doria Jr, above n 48, 26-8.

${ }^{52}$ Uruguay was the first full state party to accept the Court's jurisdiction in 2007 , followed by Argentina and Paraguay in 2008, and Brazil in 2012.

53 Porrata-Doria Jr, above n 48, 33. 
was more positive, the Permanent Review Court is a judicial institution in the loosest sense and is a rather amorphous entity, with membership changing from case to case, and members enjoying mandates of no more than two years, leaving little chance to construct a supranational legal order through a consistent body of jurisprudence. Interpretation of MERCOSUR rules and their relation to national law remains the province of national courts, with no uniform approach to the task. ${ }^{54}$ As a result, MERCOSUR cannot be considered a supranational legal order in any meaningful sense.

The Court of Justice of the Andean Community is somewhat different. The Andean Community modeled its institutional structure much more closely on the European Community (now Union), creating the Court in 1984 to adjudicate suits concerning the direct application of community law, state noncompliance with community law, preliminary references by national courts seeking interpretation of community law and challenges to the validity of decisions or actions of community institutions; the founding treaty referring expressly to the doctrine of direct effect, and implicitly, its corollary-the supremacy of community law. ${ }^{55}$

However, various tweaks afforded greater protection to national sovereignty: in particular, the Court's jurisdiction was limited to consideration of the meaning of community law and it was prohibited from considering the facts of the cases before it, leaving less scope for the expansive rulings that had become a hallmark of the European Court of Justice. Although the Andean Court in its jurisprudence expressly asserted the foundational doctrines of direct effect and supremacy, and the nature of the community as an autonomous legal order, it never took the additional step of 'constitutionalising' the founding treaties, has been much more tolerant of state deviations from community law, and did not follow the European Court's expansion of the pre-emptive force of community law. This has left states considerably more freedom to legislate in areas within the Community's competence, in comparison to EU member states. ${ }^{56}$

As regards the Court of Justice's relationship with national courts, it has placed weaker constraints on national judges in interpreting community law, adopting a more deferential posture than the European Court of Justice. ${ }^{57}$ Perhaps most importantly, whereas community law in Europe was constructed on the basis of national courts' willingness to refer provocative and fundamental

\footnotetext{
${ }^{54}$ See S Fazio, The Harmonization of International Commercial Law (2007), 106.

${ }^{55}$ KJ Alter, L Helfer and O Saldías, 'Transplanting the European Court of Justice: The Experience of the Andean Tribunal of Justice' (2012) 60 AJCL 629, 631-8.

${ }^{56}$ Ibid, $650 \mathrm{ff}$.

${ }^{57}$ Ibid, 658-9.
} 
questions of law to the European Court of Justice, leading to an unprecedented partnership of national and international judiciaries, this is not the case in the Andean context: some $90 \%$ of the references to the Court of Justice concern technical questions regarding the Andean Community's intellectual property law, and national judges appear reluctant to refer questions outside this narrow sphere. ${ }^{58}$

Thus, although the Andean Court is billed as the 'third most active international court ${ }^{59}$ in terms of its docket size (after the European Court of Justice and the European Court of Human Rights), its operation has not led to an expansive body of supranational law and the relationship between national courts and the Court of Justice is very limited, with national courts ceding little supremacy to their Andean cousin.

For all the similarities, then, and the presence of various features reminiscent of the European context, domestic courts in South America continue to burn much more brightly in the regional constellation than the adjudicative bodies of the regional integration projects.

\subsection{The Inter-American Human Rights System}

Compared to the regional integration courts discussed above, the Inter-American system for the protection of human rights has been significantly more successful.

The Inter-American system, like the European Convention system, is a post-war creation. Beginning with the creation of the Organization of American States $(O A S)$ and proclamation of the American Declaration of Human Rights $(A D H R)$ in 1948, the system owes its development in large part to a process of legal and institutional mimesis, looking to the European experience for inspiration. While its institutional development has lagged somewhat behind that of the European system, with the Inter-American Commission on Human Rights established in 1959, followed by the Court in 1978, the system is now at a level of significant maturity. The Inter-American Court of Human Rights, like the European court, represents the apogee of an incremental process of institutional development and is tasked with the interpretation of a lynchpin regional normative instrument for the protection of human rights-the American Convention on Human Rights (ACHR) adopted in 1969.

\footnotetext{
${ }^{58}$ LR Helfer \& KJ Alter, 'The Andean Tribunal of Justice and its Interlocutors: Understanding Preliminary Reference Patterns in the Andean Community' (2009) 41 NYUJILP 871.

${ }^{59}$ Alter, Helfer \& Saldía, above n 56, 629.
} 
However, the Inter-American system is far from a mere facsimile of the European system. Of particular relevance for present purposes, unlike the European system, the Inter-American system continues to operate with a non-judicial Commission and a judicial Court. In addition, acceptance of its jurisdiction was a relatively slow process, with only eight states accepting its jurisdiction by 1985 , 12 by 1990 , and 20 of the current 23 member states by 2000 . With the US and Canada declining to accept its jurisdiction it remains essentially a court for Latin America. Also, unlike the European system, individuals may not petition the Court directly; cases may be referred by the Commission, or by the State where it disputes a Commission decision against it.

As a result, the Court's jurisprudential output, though significant, is much more modest than that of the European Court: it did not issue its first decision in a contentious case, Velásquez Rodriguez v Honduras, ${ }^{60}$ until 1987, and the number of merits decisions per year issued by the Court was low until the turn of the century, hitting double digits as recently as 2004 and since then tending to vary between approximately 10 and 20 decisions annually. However, to date the Court has issued almost 200 decisions in contentious cases, as well as 20 advisory decisions, and various observers point to a rapid growth in the Court's case-load as a sign of the success and maturation of the Court and the Inter-American human rights system as a whole, with the number of cases on the Court's docket almost doubling in the past decade. ${ }^{61}$

Moreover, though modest in size, the Court's jurisprudence has had a significant impact across the region from the outset. In particular, faced from its early years with cases involving severe and widespread human rights violations-often the legacy of the authoritarian regimes across the region until the 1980s-it has no margin of appreciation doctrine like that of the European Court, which permits the latter to adopt a deferential posture towards national governments in certain cases. It has also evinced a tendency towards a 'monist' approach in some decisions, collapsing the boundary between international and domestic law. The most notable example is its landmark decision of 2001 in Barrio Altos $v$ Peru ${ }^{62}$ concerning the application of amnesty laws to the killing of civilians by a State-controlled death squad, in which the Court held the domestic amnesty law to be incompatible with the American Convention and to be devoid of legal

\footnotetext{
${ }^{60}$ Velásquez Rodríguez v Honduras (1988) IACtHR Ser C No 4.

${ }^{61}$ See: D García-Sayan, 'The Inter-American Court and Constitutionalism in Latin America' (2010) 89 Tx LR 1835; AA Cançado Trindade, 'The Developing Case Law of the Inter-American Court of Human Rights' (2003) 3 HRLR 1, 1.

${ }^{62}$ Barrio Altos v Peru (2001) IACtHR Ser C No 87.
} 
effect. $^{63}$

Notwithstanding the Inter-American Court's more assertive posture toward domestic courts, the literature suggests a 'harmonic resonance' ${ }^{64}$ between the two, with a widespread willingness on the part of constitutional courts in states such as Argentina, Colombia, Peru and Uruguay to give effect to the decisions of the Inter-American Court, ${ }^{65}$ not only concerning amnesty laws, but issues as diverse as free speech, workers' rights, the rights of indigenous peoples and the right to due process. ${ }^{66}$ A number of scholars suggest that the Inter-American Court's jurisprudence has revitalised national judiciaries. García-Sayan, for instance, asserts:

Increasingly, the highest courts of several countries of the region are taking inspiration from the Inter-American Court's jurisprudence and supplementing, in a conceptual manner, their national circumstances with certain developments of the Inter-American Court. ${ }^{67}$

Indeed, various constitutional courts (e.g. Colombia and Peru), inspired by the French doctrine of 'bloc de constitutionnalité, 68 have through their case-law elevated international human rights norms to constitutional status; conceiving constitutional law and certain international human rights norms-particularly Inter-American norms-as forming a coherent and combined set of standards for judicial review. ${ }^{69}$ Even the Chilean Constitutional Court, which eschews the formal doctrine of a 'block of constitutionality', 'reflexively' uses Inter-American jurisprudence to reinterpret domestic law. ${ }^{70}$

${ }^{63}$ D Rodríguez-Pinzón, 'The Inter-American human rights system and transitional processes' in A Buyse \& M Hamilton (eds), Transitional Jurisprudence and the ECHR: Justice, Politics and Rights (2011) 244.

${ }^{64}$ Ibid, 257.

${ }^{65}$ See: García-Sayan, above n 62; B Tittemore, 'Ending Impunity in the Americas: The Role of the Inter-American Human Rights System in Advancing Accountability for Serious Crimes Under International Law' (2006) 12 Sw J L \& Trade Am 429, 449ff.

${ }^{66}$ See: L Bugorgue-Larsen \& A Úbeda de Torres, The Inter-American Court of Human Rights: Case Law and Commentary (R Greenstein, tr; 2011).

${ }^{67}$ García-Sayan, above n 62, 1836-7.

${ }^{68}$ The doctrine derives from a 1971 decision of the Constitutional Council (Conseil Constitutionnel) that held the Declarations of Rights of 1789 and 1946 may be used as standards for constitutional interpretation, alongside the Constitution of 1958.

${ }^{69}$ See: ME Góngora Mera, Inter-American Judicial Constitutionalism: On the Constitutional Rank of Human Rights Treaties in Latin America Through National and Inter-American Adjudication (2011).

${ }^{70}$ See: ibid, 139; M Torelly, 'Transnational Legal Process and Constitutional Engagement in Latin 
Yet, state compliance with the Court's decisions is considerably lower than European compliance patterns ${ }^{71}$ and only gradually improving. ${ }^{72}$ The support of key OAS member states is also often lacking: the regional hegemon, Brazil, was among the last to submit to its supervision ${ }^{73}$ and a lack of financial support has tended to adversely affect the system's effectiveness, requiring the EU on occasion to step into the budgetary breach. ${ }^{74}$ The Court was dealt a significant blow in 2012 with Venezuela's denunciation of the American Convention on Human Rights, which freed it from the Court's jurisdiction; a move which had been actively urged by the Venezuelan Supreme Court. ${ }^{75}$ In addition, as discussed below, the Supreme Federal Court of Brazil appears to hold a decidedly frosty stance toward the Inter-American Court which has dulled the impact of Inter-American jurisprudence in South America's most populous state.

The Inter-American human rights system, as a result, is a success story, but a qualified one. Although it has enhanced judicial dialogue and a sense of a common enterprise across the region concerning judicial protection of human rights it has been fully operational for a much shorter period than the European Court, and operates in a less stable setting than the European Court which, despite threats from Westminster and an overwhelming docket, enjoys higher compliance levels and institutional security.

America: How do Domestic Constitutional Regimes deal with International Human Rights Law?' (Society of Legal Scholars Graduate Conference on Latin American Law and Policy, Oxford, 7 March 2014) 31.

${ }^{71}$ See: M Tan, 'Member State Compliance with Judgments of the Inter-American Court of Human Rights' (2005) 33 Int'l J Leg Info 319.

72 See: DA González-Salzburg, 'Complying Partially with the Judgments of the Inter-American Court of Human Rights' (Society of Legal Scholars Graduate Conference on Latin American Law and Policy, Oxford, 7 March 2014).

${ }^{73}$ Brazil was one of the last members of the Organisation of American States (OAS) to ratify the Inter-American Convention on Human Rights (in 1992) and to accept the jurisdiction of the Inter-American Court of Human Rights (in 1998). See: C MacDowell Santos, 'Transnational Legal Activism and the State: Reflections on Cases Against Brazil in the Inter-American Commission on Human Rights' (2007) 7 IACmHR Ann Rep 29, 36.

${ }^{74}$ See: V Rodriguez Rescia and MD Seitles, 'The Development of the Inter-American Human Rights System: A Historical Perspective and a Modern-Day Critique' (2000) 16 NYLSJHR 593; JL Cavallaro \& SE Brewer, 'Reevaluating Regional Human Rights Litigation in the Twenty-First Century: The Case of the Inter-American Court' (2008) 102 AJIL 768, 782-3.

${ }^{75}$ See: A Huneeus, 'Courts Resisting Courts: Lessons from the Inter-American Court's Struggle to Enforce Human Rights’ (2011) 44 Cornell ILJ 493, 500. 


\subsection{Judicial Networks}

In line with the above, formal judicial networks in South America are less developed than those in Europe.

Reflecting the lack of any judicial architecture in the embryonic infrastructure of UNASUR, there does not appear to be any judicial network operating under its aegis. More surprising is the apparent absence of any such network for the Andean Community. In the MERCOSUR context there is a Permanent Forum of the Supreme Courts of the trading bloc, ${ }^{76}$ established in 2004 and with headquarters in Brasília, which facilitates yearly and ad hoc meetings of judges as well as a judicial exchange programme for member states of MERCOSUR and associated states. ${ }^{77}$ Maria Ângela Jardim de Santa Cruz Oliveira, an official at the Brazilian Supreme Court, paints a positive picture of the permanent forum as linking courts and fostering development of procedure at the Permanent Review Court. ${ }^{78}$ However, its activity appears to be quite limited given the inertia of the MERCOSUR organs themselves and there is, at best, a faint echo of the use of judicial networks in Europe to balance member state disagreement on harmonising national laws. In addition, it appears aimed at linking the national courts, with little focus on fostering links with the Permanent Review Court itself, and is organised by the Brazilian Supreme Court rather than MERCOSUR itself. ${ }^{79}$

There do not appear to be any judicial networks in the OAS targeted at judges, with the most important OAS network for legal cooperation focused on ministers of justice and attorneys general. ${ }^{80}$ In addition, the membership of the Inter-American Court, unlike that of the European Court of Human Rights (for good or ill), does not include a judge for each member state but a fixed number of seven judges, which leaves fewer national 'judicial ambassadors' for the Court

\footnotetext{
${ }^{76}$ The body is formally known as the Permanent Forum of Supreme Courts of Mercosur countries for judicial matters relevant to Latin-American integration, with a specific emphasis on Mercosur'. See: MA Jardim de Santa Cruz Oliveira, 'Judicial Diplomacy: The Role of the Supreme Courts in Mercosur Legal Integration' (2007) 48 Harvard ILJ Online 93, 95 $<$ http://www.harvardilj.org/wp-content/uploads/2011/05/HILJ-Online_48_Oliveira.pdf> [accessed 1 January 2015].

${ }^{77}$ See: $\quad<$ http://www2.stf.jus.br/portalStfInternacional/cms/verConteudo.php?sigla=portalStfCooperacao_en_ us\&idConteudo $=188385>$ [accessed 1 January 2015].

${ }_{78}^{78}$ Jardim de Santa Cruz Oliveira, above n 76.

${ }^{79}$ The judicial exchange programme is named after a Brazilian supporter of Pan-Americanism: 'the Joaquim Nabuco exchange program for judges and judicial servants within Mercosur and Associate States'.

${ }^{80}$ The Hemispheric Information Exchange Network for Mutual Assistance in Criminal Matters and Extradition. See: <http://www.oas.org/Juridico/mla/en/> [accessed 1 January 2015].
} 
across the region. There is, for instance, no judge from Argentina, Paraguay, Ecuador or Bolivia on the current Court, although the use of ad hoc judges may offset this somewhat. ${ }^{81}$ Further, unlike the European Convention system, which has enjoyed the normative ballast provided by the European Union (and its previous iterations), the Inter-American system has not evolved in partnership with a sister regional integration project, and unlike the intense engagement between the Luxembourg and Strasbourg courts, the Inter-American Court in San José appears to have few meaningful links with the courts of the regional integration bodies.

The main regional network for the region under the 'Venice Commission' system $^{82}$ is the Ibero-American Conference of Constitutional Justice, which includes most hispanophone states in Latin America, along with Andorra, Portugal and Spain. However, its activity appears to consist mainly of an annual conference. $^{83}$

Besides these bodies, courts in South America tend to be members of bodies that transcend the region: Brazil, for example, is the only South American member of the Conference of Constitutional Jurisdictions of the Portuguese-Speaking Countries (CJCPLP); and Brazil and Chile are the only South American members of the Venice Commission and its Joint Council on Constitutional Justice. Brazil has also fostered a Forum of Supreme Courts of BRIC states (Brazil, Russia, India, China), which is at least as developed as the MERCOSUR forum, ${ }^{84}$ and also hosted the second congress of the Venice Commission-backed World Conference of Constitutional Justice in $2011 .{ }^{85}$ Indeed, Brazil appears to be the regional leader in the field of 'judicial diplomacy'; as a complement to its vigorous international diplomacy aimed at enhancing the state's stature and power at both the regional

\footnotetext{
$\overline{81}$ The current justices are from Brazil, Colombia, Costa Rica, Chile, Peru, Uruguay and Mexico. The Court's rules of procedure since 2001 have allowed respondent states to appoint ad hoc judges for cases in which there is no judge of the respondent State's nationality. See M Feria Tinta, "Dinosaurs" in Human Rights Litigation: The Use of Ad Hoc Judges in Individual Complaints before the Inter-American Court of Human Rights' (2004) 3 LPICT 79, 79.

${ }^{82}$ The Venice Commission has been a key driver in the establishment and linking of regional judicial networks worldwide, such as the Conference of Constitutional Control Organs of the Countries of New Democracy (CCCOCND) and the Union of the Arab Constitutional Councils and Courts (UACCC), as well as the global constitutional court network, the World Conference on Constitutional Justice (WCCJ).

${ }^{83}$ See: <http://www.cijc.org/Paginas/Default.aspx> [accessed 1 January 2015].

${ }^{84}$ See: $\quad<$ http://www2.stf.jus.br/portalStfInternacional/cms/verConteudo.php?sigla=portalStfCooperacao_en_us\&id Conteudo $=160010>$ [accessed 1 January 2015].

${ }^{85}$ See: <http://www.venice.coe.int/wccj/wccj_e.asp> [accessed 1 January 2015].
} 
and global levels. ${ }^{86}$

In comparison to the European context, then, there appear to be significantly fewer judicial networks in South America; and, in particular, little formal networking between national courts and regional international courts. This is not to say that there is no regional judicial community in South America but simply, that it is of a different order to the intense and overlapping community found in the EU.

\section{Taking a Closer Look: The Supreme Courts of Argentina and Brazil Compared}

Thus far, it appears that judicial interaction within the Inter-American human rights system is the most marked example in South America of law and courts transcending state boundaries, and the evolution of a true epistemic community. A quick comparison of two South American supreme courts allows a deeper exploration of this regime, to achieve a more fine-grained understanding of universality, cosmopolitanism and internationalisation in the region.

\subsection{The Supreme Court of Argentina: Swinging between Universalism and Cosmopolitanism}

In a region where constitutions commonly accord constitutional rank to international human rights law the Constitution of Argentina has taken an unusual route. Constitutional reforms in 1994, little over a decade after the collapse of military rule, left the nineteenth-century constitutional provisions on fundamental rights in situ but amended Article 75(22) to accord express constitutional status to nine international and regional human rights treaties, without incorporating them textually. ${ }^{87}$ The doors of the constitutional order, it seemed, had been thrown open to universal norms.

\footnotetext{
${ }^{86}$ See: M Herz, 'Brazil: Major Power in the Making?' in TJ Volgy, R Corbetta, KA Grant \& RG Baird (eds), Major Powers and the Quest for Status in International Politics: Global and Regional Perspectives (2011) $160 \mathrm{ff}$.

${ }^{87}$ The nine treaties are: (i) The American Declaration of the Rights and Duties of Man (ADHR); (ii) the Universal Declaration of Human Rights (UDHR); (iii) the American Convention on Human Rights (ACHR); (iv) the International Covenant on Economic, Social and Cultural Rights (ICESCR); (v) the International Covenant on Civil and Political Rights (ICCPR); (vi) the Convention on the Prevention and Punishment of Genocide; the International Convention on the Elimination of All Forms of Racial Discrimination (ICERD); (vii) the Convention on the Elimination of All Forms of Discrimination Against Women (CEDAW); (viii) the Convention
} 
Scholars have noted the potential of the reforms to effect a dramatic transformation of the constitutional order: national courts would become 'the domestic transmission belt, ${ }^{88}$ transporting international human rights norms to individual cases in a context where, not only the American rights instruments, but the entire normative framework of the Inter-American human rights system had been 'internalised'; introducing a 'paradigmatic shift' ${ }^{89}$ concerning the domestic courts' stance towards the decisions of the Inter-American Commission and Court by according constitutional recognition to the binding nature of the Court's judgments; ${ }^{90}$ and possibly transforming the Inter-American organs into 'appellate-like tribunals'.91

Certainly, from 1995 the Supreme Court, having equivocated in its previous jurisprudence concerning the precise status of international human rights law, ${ }^{92}$ appeared to move toward greater recognition of the Inter-American Court's jurisprudence. The Supreme Court not only recognised that the jurisprudence of the Inter-American Court should guide it in interpreting the ACHR, but further, that even case-law concerning other States might be seen as binding. This is seen to full effect in the Court's Simon ${ }^{93}$ decision of 2005, in which the Court invalidated Argentina's amnesty laws in compliance with long-standing Inter-American jurisprudence in the area. ${ }^{94}$

However, the Simon decision also laid bare enduring uncertainty concerning the precise nature of the change effected by the 1994 reforms to the status of international human rights law. ${ }^{95}$ A majority of the judges hitched their wagon to international norms, including ius cogens and human rights treaties, arguing that the 1994 reforms would require, at times, exceptions to the Constitution

Against Torture and other Cruel, Inhuman or Degrading Treatments or Punishments (CAT); and (ix) the Convention on the Rights of the Child (CRC).

${ }^{88}$ JK Levit, 'The Constitutionalization of Human Rights in Argentina: Problem or Promise?' (1999) 37 Cornell JIL 281, 329.

${ }^{89}$ DA Gonzalez-Salzburg, 'The Implementation of Decisions from the Inter-American Court of Human Rights in Argentina: An Analysis of the Jurisprudential Swings of the Supreme Court' (2011) 15 SUR-IJHR 113, 114.

90 Ibid, 121.

${ }^{91}$ Levit, above n 88, 329-30.

92 The Supreme Court's jurisprudence suggested until 1992 a general rule that later norms (whether national or international) supersede earlier ones, and, from 1992, that such treaties lay somewhere between statute law and the constitution.

${ }^{93}$ Simon, Julio Hector y otros, 328 Fallos 2056 (2005).

${ }^{94}$ Gonzalez-Salzburg, above n 89, 121.

95 See: NP Sagüés (tr K Rosenn), 'An Introduction and Commentary to the Reform of the Argentine National Constitution' (1996) 28 U Miami Inter-Am LR 41. 
to be recognised or 'bubbles' in the constitution into which the Court would insert external norms-in the instant case, invalidation of the amnesty law to facilitate prosecution of former military actors necessitated contravention of the constitutional principle against retroactivity in criminal law. However, as José Elias has noted, the justices failed to elaborate any firm criteria for doing so. ${ }^{96}$ The precise status of international human rights law in Argentina's constitutional order-and by extension, the case-law of the Inter-American Court-was thus left rather opaque.

Indeed, as Damián González-Salzburg has observed, the Court's case-law on the binding nature of Inter-American Court decisions against Argentina has been quite inconsistent, with the Supreme Court emphasising in 2004 the need to subordinate itself to decisions of the Inter-American Court due to the binding nature of the latter's judgments, but handing down decisions since then that directly contravene those of the Inter-American Court, and, at times, even ignoring the Court's case-law in its reasoning. Although it appears to be slowly returning to its 2004 stance in its more recent decisions it is unclear whether it will succumb to yet another "jurisprudential swing.97

The Argentine context, then, may look at first glance like an extreme example of internationalisation, with the full reception of universal international norms and regional norms into the domestic order, and the voluntary recognition of Inter-American case-law as binding. However, it is best described as a sort of cosmopolitanism, with the Supreme drawing on Inter-American norms only when this suits its purposes and declining to do so when this tends to frustrate its desired outcome.

\subsection{The Supreme Federal Court of Brazil: A Sovereigntist Cosmopolitanism}

The 1988 Constitution of Brazil, adopted to replace the authoritarian text of 1969, is 'the most stunning, ${ }^{98}$ example of the tendency of some South American states to incorporate both the spirit and text of international human rights treaties. Article 5 of the Constitution enshrines a vast range of justiciable civil and political rights, and social and economic rights; textually incorporating all but one of the rights

\footnotetext{
${ }^{96}$ See: JS Elias, 'Constitutional Changes, Transitional Justice, and Legitimacy: The Life and Death of Argentina's “Amnesty” Laws' (2008) 31 Hastings ICLR 587, 628-44.

${ }^{97}$ Gonzalez-Salzburg, above n 89, 121-4.

${ }^{98}$ Levit, above n 88, 294, 298 (fn 80).
} 
enumerated in the International Covenant on Civil and Political Rights (ICCPR) and the American Convention on Human Rights (ACHR). ${ }^{99}$

This approach served to 'domesticate' international human rights law rather than elevate such law in the constitutional order. Until 2004 international human rights treaties were accorded sub-constitutional status, with the Supreme Court generally applying the 'later in time' (lex posterior) rule, allowing treaties to be superseded by subsequent domestic legislation. However, a constitutional amendment of 2004 (No 45/2004) enhanced the status of international human rights treaties, amending Article 5 of the Constitution to hold that international human rights treaties and conventions approved by a supermajority of Congress (i.e. by three-fifths of those voting, in two rounds) are equivalent to constitutional amendments; the move appearing to reflect a political desire to 'internationalise' the constitutional order.

In a 2008 judgment the Supreme Court had the opportunity to address the precise nature of the reform in a case concerning a direct clash between provisions of the constitution and the ACHR regarding the imprisonment of debtors. 100 As Gustavo Ferreira Santos notes, the vote of Justice Gilmar Mendes examined the issue in the most depth, seeking to consolidate the Court's jurisprudence to date on the relationship between constitutional law and international law, and acknowledging the global tendency toward 'internationalisation' of constitutional law. ${ }^{101}$ Justice Mendes recognised that simply following the 'later in time' rule, would be problematic, allowing international treaties to be superseded by domestic legislation. However, as regards the constitutional amendment of 2004, he made a clear distinction between international treaties adopted before and after the amendment came into force. While the latter would attain constitutional status, the former would be accorded an intermediate status; supralegal but sub-constitutional, and therefore not subject to the 'later in time' rule, but still subject to compliance with the Constitution. ${ }^{102}$ In doing so, Justice Mendes eschewed the adoption of a 'block of constitutionality' doctrine akin to that of other South American constitutional courts, and urged by a minority of justices in the case. ${ }^{103}$

\footnotetext{
${ }^{99}$ An English translation of the Federal Constitution is available on the Venice Commission's CODICES database: <http://www.codices.coe.int/NXT/gateway.dll?f=templates\&fn=default.htm $>$ [accessed 2 November 2013].

${ }^{100} \mathrm{RE} 349703$ (3 December 2008).

${ }^{101}$ GF Santos, 'Treaties X Human Rights Treaties: A Critical Analysis of the Dual Stance on Treaties in the Brazilian Legal System' (2013) 15 EJLR 20, 28.

${ }^{102}$ Ibid, 29.

${ }^{103}$ See: AM Maués, 'Supra-legality of International Human Rights and Constitutional Interpreta-
} 
A central result of the decision was to limit the impact of the Inter-American system in the domestic order, given that Brazil had ratified the ACHR in 1992long before adoption of the constitutional amendment of 2004. It forms part of a discernible pattern in the Court's jurisprudence toward keeping Inter-American jurisprudence at arm's length. The Supreme Federal Court, in stark contrast to courts in neighbouring states, very rarely refers to Inter-American Court jurisprudence, ${ }^{104}$ has never used it as an interpretive standard in judicial review, and has handed down decisions which conflict with established Inter-American jurisprudence. ${ }^{105}$ Further, despite being a key actor in 'judicial diplomacy' with supreme courts of MERCOSUR states, BRIC states and European states, the Supreme Federal Court has not fostered any links with the Inter-American Court.

This, it must be emphasised, is unlike the opposition in certain quarters of the US Supreme Court to the citation of foreign jurisprudence. Indeed, the Supreme Federal Court has become progressively more open to citing a wide range of external jurisprudence over the past three decades, moving from an overwhelming focus on the US Supreme Court and the Federal Constitutional Court of Germany to embrace other courts, including the European Court of Human Rights, without any controversy. ${ }^{106}$

tion' (2013) 18 SUR-IJHR 205.

${ }^{104} \mathrm{Da}$ Silva notes that in a review of 138 decisions of the Court, not one made reference to the Inter-American Court's case-law. See: Santos, above n 101, 26-7. Analysis by the present author of a selected list of the Supreme Federal Court's most important decisions, provided on the Court's website (the majority of which were decided after Brazil's acceptance of the Inter-American Court's jurisdiction in 1998) similarly reveals occasional citations of American, German, Spanish, Italian and European Court of Human Rights jurisprudence but no citation of Inter-American Court jurisprudence. See: <http://www.stf.jus.br/portal/jurisprudenciaTraduzida/jurisprudenciaTraduzida.asp $>$ [accessed 1 January 2015]. That is not to say that the Supreme Court never cites Inter-American Court jurisprudence-see, for example, the Court's heavy reliance on a Consultative Opinion of the Inter-American Court concerning diploma requirements for journalists, in RE 511.961 (17 June 2009). However these are rare occasions and do not address the status of such jurisprudence or form part of any systematic approach of the Supreme Court toward such jurisprudence.

${ }^{105}$ In its April 2010 decision on the validity of Brazil's 1979 Amnesty Law the Supreme Court refused to invalidate the law in line with Inter-American Court jurisprudence: ADPF 153 (29 April 2010). Six months later, the Inter-American Court held that certain provisions of the Amnesty Law, in precluding the investigation and punishment of severe human rights violations, are incompatible with the American Convention and have no legal basis; Gomes Lund and others ('Guerrilha do Araguaia') v Brazil (2010) IACtHR Ser C No 219.

${ }^{106}$ In his review of 138 decisions of the Court, da Silva found no less than 80 references to decisions of the US Supreme Court and 58 references to case-law of the Federal Constitutional Court of Germany. See: Santos, above n 102, 26-7. Expansion of the Court's range of reference is 
It is this strong tradition of citing foreign jurisprudence which leads one to surmise that the Court' resistance to citing the case-law of the Inter-American Court is based on a resistance to being bound by another judicial body; a conclusion bolstered by the Court's apparent reluctance to share judicial supremacy with other international adjudicative bodies. For example, in 2007, the Appellate Body $(A B)$ of the World Trade Organisation (WTO) found Brazil's ban on imports of re-treaded tyres, from which MERCOSUR members were exempted, to constitute arbitrary treatment in violation of the General Agreement on Trades and Tariffs (GATT). However, in 2009, in seeming contravention of that decision, the Supreme Court upheld the import prohibition as constitutional, declaring that any decision to import re-treaded tyres in Brazil (including from MERCOSUR) is unconstitutional and emphasising its position as having the final say in the matter. $^{107}$

Thus, despite political moves to internationalise the Brazilian constitution and the Court's clear openness to external jurisprudence, the Supreme Federal Court appears wedded to what might be termed a 'sovereigntist' approach, with the Court as gate-keeper of the domestic order in a more traditional conception of the division of domestic and international law than that of its neighbours. Given Brazil's status as the regional hegemon it is tempting to liken this scenario to the unthinkable prospect of the Federal Constitutional Court of Germany declining to foster any relationship with the European Court of Human Rights, but it suffices to simply observe that it is a far cry from anything seen in the European context, where occasional friction between national courts and regional courts occurs in a general context of mutual respect, cooperation and recognition.

\section{Conclusion: Baby steps away from the State}

The overall point of this brief tour d'horizon of judicial dialogue and community in South America is that our sense of the twilight of the state is ultimately a matter of perspective. From Berlin, Bratislava or Birmingham, law and the

evidenced in its 2012 decision on abortion in cases of anencephaly, in which the Court cited not only decisions of the constitutional courts of Germany, Italy, Spain and the US, but also the European Court of Human Rights and the UN Human Rights Committee. See ADPF 54 (12 April 2012).

${ }^{107}$ ADPF 101 (24 June 2009). An overview of the case is provided in 'General Overview of Active WTO Dispute Settlement Cases Involving the EU as Complainant or Defendant and of Active Cases Under the Trade Barriers Regulation' (European Commission) $7-8<$ http://trade.ec.europa.eu/doclib/docs/2007/may/tradoc_134652.pdf> [accessed 8 November 2013]. 
courts appear to be striding away from the state, with the centrality of the state diluted in a complex cocktail of supranational law, regional human rights law and international law. From Brasília, Bógota or Buenos Aires-and certainly, for that matter, Beijing, Brisbane, Bishkek or Bombay-the diminution of the state is far less pronounced.

This conclusion, it should be emphasised, is not based on any form of statist nostalgia, nor any denial of the general global trend toward legal orders that transcend the state, but on the reality of regional integration in South America and the state of development of judicial dialogue and community when they are probed beyond their surface similarities to the European experience. Law and the courts may be stepping away from the state in South America. However, these have been, to date, no more than baby steps. 